\title{
Mapping freshwater snails in north-western Angola: distribution, identity and molecular diversity of medically important taxa
}

Fiona Allan ${ }^{1,2^{*}+}$, Jose Carlos Sousa-Figueiredo ${ }^{1,3+}{ }^{4}$ Aidan M. Emery ${ }^{1,2}$, Rossely Paulo ${ }^{3,4}$, Clara Mirante ${ }^{3}$, Alfredo Sebastião ${ }^{3}$, Miguel Brito 3,5 and David Rollinson ${ }^{1,2}$

\begin{abstract}
Background: This study was designed to determine the distribution and identity of potential intermediate snail hosts of Schistosoma spp. in Bengo, Luanda, Kwanza Norte and Malanje Provinces in north-western Angola. This is an area where infection with Schistosoma haematobium, causing urogenital schistosomiasis, is common but little is yet known about transmission of the disease. Angola has had a varied past with regard to disease control and is revitalising efforts to combat neglected tropical diseases.
\end{abstract}

Methods: Snails were sampled from 60 water-contact points. Specimens of the genera Bulinus, Biomphalaria or Lymnaea were screened for trematode infections by inducing cercarial shedding. Snails were initially identified using shell morphology; subsequently a cytochrome c oxidase subunit 1 (cox1) gene fragment was amplified from a subset of snails from each site, for molecular identification. Cercariae were captured onto FTA cards for molecular analysis. Specimens of Bulinus angolensis collected from the original locality of the type specimen have been characterised and comparisons made with snails collected in 1957 held at the Natural History Museum, London, UK.

Results: In total snails of nine genera were identified using morphological characteristics: Biomphalaria, Bulinus, Gyraulus, Lanistes, Lentorbis, Lymnaea, Melanoides, Physa and Succinea. Significant for schistosomiasis transmission, was the discovery of Bulinus globosus, B. canescens, B. angolensis, B. crystallinus and Biomphalaria salinarum in their type-localities and elsewhere. Bulinus globosus and B. angolensis occurred in two distinct geographical areas. The cox1 sequence for B. globosus differed markedly from those from specimens of this species collected from other countries. Bulinus angolensis is more closely related to B. globosus than originally documented and should be included in the B. africanus group. Schistosoma haematobium cercariae were recovered from B. globosus from two locations: Cabungo, Bengo (20 snails) and Calandula, Malanje (5 snails). Schistosoma haematobium cercariae were identified as group 1 cox 1 corresponding to the type common throughout the African mainland.

Conclusions: Various freshwater bodies in north-western Angola harbour potential intermediate snail hosts for urogenital schistosomiasis, highlighting the need to map the rest of the country to identify areas where transmission can occur and where control efforts should be targeted. The molecular phylogeny generated from the samples confirmed that considerable variation exists in B. globosus, which is the primary snail host for S. haematobium in many regions of Africa.

Keywords: Angola, Schistosomiasis transmission, Bulinus globosus, Biomphalaria spp., Schistosoma haematobium

\footnotetext{
* Correspondence: f.allan@nhm.ac.uk

${ }^{\dagger}$ Equal contributors

${ }^{1}$ Department of Life Sciences, Natural History Museum, Wolfson Wellcome

Biomedical Laboratories, Cromwell Road, London SW7 5BD, UK

${ }^{2}$ London Centre for Neglected Tropical Disease Research, London, UK

Full list of author information is available at the end of the article
} 


\section{Background}

Intestinal and urogenital schistosomiasis, caused by the trematode worms Schistosoma mansoni and S. haematobium, respectively, are endemic in Angola. In 2010, the World Health Organization (WHO) estimated that 60\% of Angola's population were living at significant risk of schistosomiasis infection and required preventive chemotherapy [1]. This prevalence equates to 14.6 million people according to the most recent census [2]. However, these estimates are based on surprisingly few epidemiological surveys and non-systematically gathered data. Due to this lack of up-to-date information, there is an urgent need for further investigations relating to schistosomiasis and other neglected tropical diseases (NTDs) in Angola encompassing epidemiology, transmission studies and operational research.

While much can be done to control morbidity of schistosomiasis using large-scale community or school mass drug administration of praziquantel [3, 4], it is clear that sustainable control and elimination will need a better understanding of transmission and water contact, as highlighted in the WHO roadmap for control of NTDs [5]. Like many other sub-Saharan African countries, Angola is now mapping schistosomiasis, among other NTDs, in humans. However, very little is known about the diversity of freshwater snails responsible for transmission; in fact, the last large-scale survey of freshwater snails was published more than 50 years ago by Wright in 1963 [6].

Looking back further, to the work of Morelet in 1866 and 1868 [7, 8], it is clear that Angola is an important country in the history of medical malacology, from which many important snails were first described. In fact, the typelocalities of many species of Bulinus and one species of Biomphalaria are in Angola: Bulinus globosus (Morelet, 1866), River Dande, Bengo Province; B. angolensis (Morelet, 1866), district of Duque de Braganza (now Calandula); $B$. canescens (Morelet, 1868), marshes near River Bengo near Quicuxi; B. crystallinus (Morelet, 1868); river close to Golungo Alto and Biomphalaria salinarum (Morelet, 1868), tributaries to the River Cuije near Malange (see Brown [9]). Snails from Angola have not previously been collected and examined by modern methods of molecular characterization; hence, there is a need to carry out a comprehensive study to learn more about schistosomiasis and the snails responsible for the transmission of this debilitating disease in Angola and their relationships with other African taxa.

This investigation aimed to determine freshwater snail biodiversity and to identify potential intermediate snail hosts of schistosomes in four provinces in north-western Angola. By collecting fresh samples, comparing them to samples collected in the same locations by C. A. Wright nearly 60 years before [6], and subjecting them to modern molecular analysis we attempted to better characterise the species of the genera Bulinus and Biomphalaria currently found in Angola and to provide new molecular markers for species identification.

\section{Methods}

Locations

Fieldwork was conducted during November and December 2013, by JCSF, AL, AMS, CM and DR. The Dande, Bengo, Kwanza, Lucala and Cuije river basins were visited. Accordingly, a total of four provinces were visited and extensively surveyed: Bengo (25 sites), Luanda (10 sites), Kwanza Norte (12 sites) and Malanje (13 sites), see Fig. 1a for graphical representation and Table 1 for site details.

\section{Malacology procedures}

Water bodies were examined for freshwater snails using a standard protocol [9]. Information was recorded on pre-designed forms and included: general locality information (water body name, type, GPS coordinates, nearby village); water properties data (temperature, $\mathrm{pH}$, salinity, dissolved solids, flow rate, water level, conductivity, depth); collector information (number of collectors, time/length of time of collection), ecological data (substrate, all species of snail present, vegetation, animal contact, human contact), and snail data (snails species, abundance, number infected).

Snails were collected using large scoops, hand sieves and forceps for approximately $22 \mathrm{~min}$ per site usually with 3-4 persons. Snails were carefully picked out with forceps taking care not to damage the shells. The collection at each site was separated into genera and placed in screw cap pots with clean mineral water before securing in a cooler with ice packs (when available) for transportation. Photographs were taken of each site visited. Upon return to Centro de Ivestigação em Saúde de Angola (CISA) (Angolan Health Research Center, in Caxito) Bulinus and Biomphalaria specimens were placed in fresh water and checked for the shedding of cercariae by exposing them to a lamp or sunlight, any emerging cercariae were examined under the microscope and identified by morphology. Snails were screened, individually, for a period of $24 \mathrm{~h}$ and then fixed in ethanol. Individual cercariae in $4 \mu \mathrm{l}$ of water, collected by pipetting, were placed onto Whatman FTA Classic cards (GE Healthcare Life Sciences, Amersham, UK) for future molecular analyses [10]. Snails were relaxed by briefly placing in a $-20{ }^{\circ} \mathrm{C}$ freezer and then fixed in ethanol (95\%). Screw top $25 \mathrm{ml}$ universal tubes were labelled both internally using pencil and parchment paper and externally with permanent marker. 


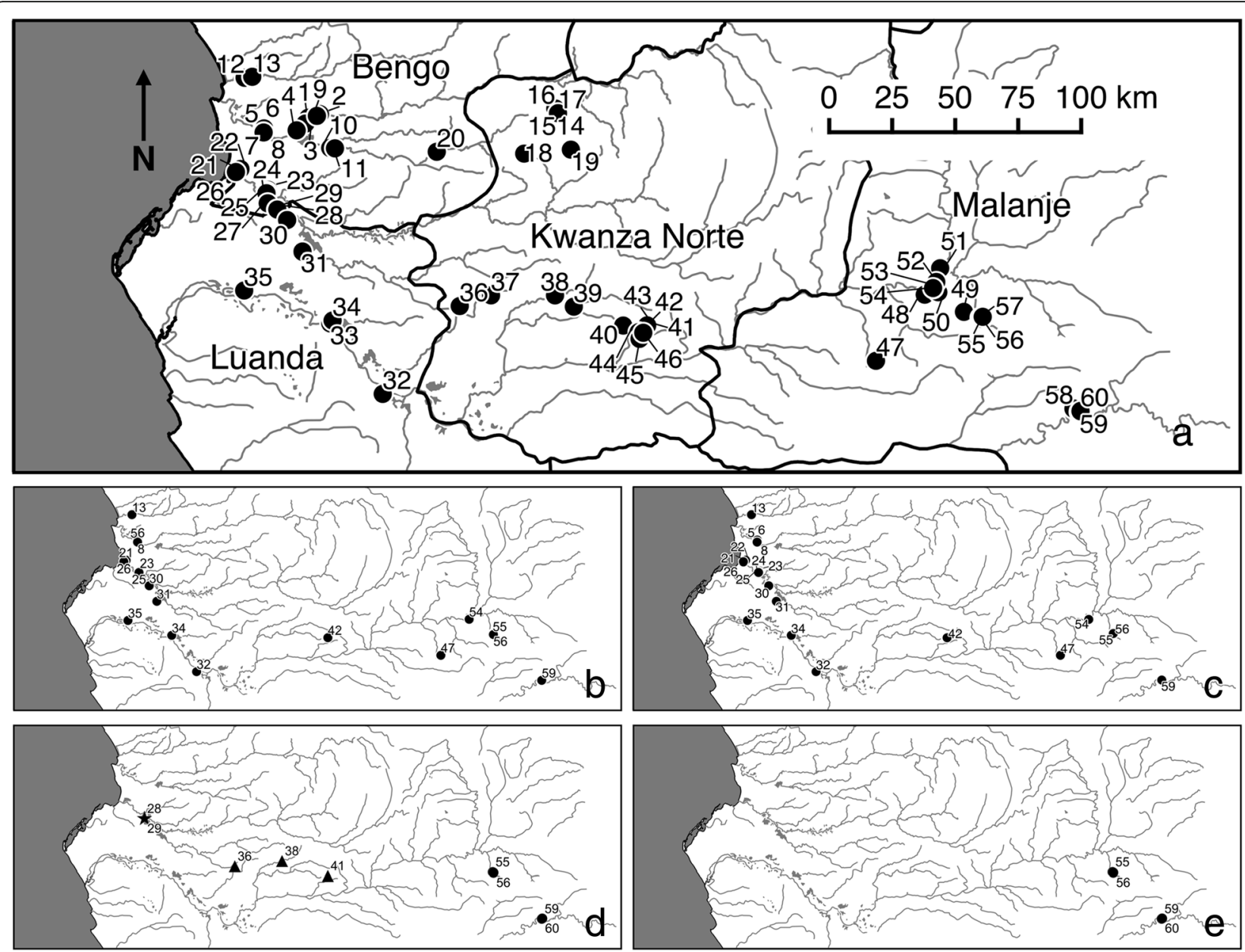

Fig. 1 Site location maps. a All sites visited in this study. b-e Sites where the following species were found: b Bulinus gobosus; c Bulinus truncatus; d Bulinus canescens (star), Bulinus crystallinus (triangle) and Bulinus angolensis (circle); e Biomphalaria salinarum

\section{Molecular characterization studies}

\section{Sample preparation and DNA extraction}

The snail samples selected for the molecular analyses represented individuals from each collection site. Examples of all species of Bulinus and Biomphalaria found in this collection trip were included. Additionally, a single sample from C. A. Wright's 1957 collection held at the Natural History Museum was included in these analyses. All specimens were stored in $95 \%$ ethanol in the field and the number of snails recounted, identified by morphological characters and re-spirited (absolute ethanol) on arrival at the Natural History Museum, London (NHM) for incorporation in to the Schistosomiasis Collection at the Natural History Museum (SCAN) [11]. Photographic images were taken of the snail shells prior to DNA extraction. Specimens were placed in TE buffer (10 mM Tris, $0.1 \mathrm{mM}$ EDTA) $\mathrm{pH} 7.4$ for $1 \mathrm{~h}$ in order to remove any remaining alcohol from within the tissue, which might interfere with subsequent extraction techniques. Total genomic DNA was isolated from head-foot snail tissue using the DNeasy Blood and Tissue kit (Qiagen, Crawley, UK) according to the manufacturer's instructions except that the volume of buffers was doubled. DNA was eluted into $200 \mu \mathrm{l}$ sterile water.

\section{Amplification of cox 1 fragments of snail DNA}

A polymerase chain reaction (PCR) amplification of a partial cytochrome $c$ oxidase subunit 1 ( $\operatorname{cox} 1$ ) sequence was performed using primers LCO1490 (5'-GGT CAA CAA ATC ATA AAG ATA TTG G-3' forward) and HCO2198 (5'-TAA ACT TCA GGG TGA CCA AAA AAT CA-3' reverse) [12]. PCR investigations and sequencing conditions were chosen as previously outlined [13]. A second set of primers was required for the PCR and sequencing of B. globosus and B. angolensis specimens; these were designed using whole mitochondrial genome data for these species (novel): BulAng61F (5'-GTA TGA TGC GGC CTG GTA GG-3') and BulAng895R (5'-AAG CCC GAG TAT CCA CAT CT-3'). 
Table 1 Sites visited during field-work

\begin{tabular}{|c|c|c|c|c|c|c|c|}
\hline Code & Name & Province & Type & Closest village & Latitude (E) & Longitude (S) & Altitude ${ }^{a}$ \\
\hline 1 & Mabubas Dam & Bengo & Dam & Mabubas & 13.6999 & 8.5343 & 70 \\
\hline 2 & River Dande and marshes & Bengo & Marshes & Sogramo Farm & 13.74204 & 8.52106 & 65 \\
\hline 3 & Caxito canal (North) & Bengo & Canal & Caxito & 13.68946 & 8.55546 & 33 \\
\hline 4 & Caxito canal (Centre) & Bengo & Canal & Caxito & 13.65779 & 8.57986 & 19 \\
\hline 5 & $\begin{array}{l}\text { Cabungo stream (type-locality } \\
\text { for Bulinus globosus) }\end{array}$ & Bengo & Stream & Cabungo & 13.53737 & 8.57579 & 22 \\
\hline 6 & Lake Cabundo & Bengo & Lake & Cabungo & 13.53983 & 8.57282 & 19 \\
\hline 7 & Natural dam & Bengo & Dam & Cabungo & 13.53779 & 8.58734 & 12 \\
\hline 8 & Irrigation canal & Bengo & Canal & Cabungo & 13.53824 & 8.58765 & 22 \\
\hline 9 & River Dande flood plain & Bengo & River & Talelo & 13.731 & 8.52747 & 69 \\
\hline 10 & Decomissioned irrigation canal & Bengo & Canal & Icau Centro & 13.77906 & 8.64375 & 42 \\
\hline 11 & $\begin{array}{l}\text { Lake formed by the River Úcua } \\
\text { floodplain }\end{array}$ & Bengo & Lake & Icau Wando & 13.79642 & 8.6451 & 49 \\
\hline 12 & River Lifune & Bengo & River & Libongo & 13.46949 & 8.39041 & 56 \\
\hline 13 & Irrigation canal close to Libongo & Bengo & Canal & Libongo & 13.49718 & 8.38692 & 56 \\
\hline 14 & River Tanda (downstream of dam) & Bengo & River & Quibaxe & 14.59702 & 8.51995 & 758 \\
\hline 15 & River Tanda (upstream of dam) & Bengo & River & Quibaxe & 14.59674 & 8.52083 & 762 \\
\hline 16 & Stream Quizende & Bengo & Stream & Quibaxe & 14.59362 & 8.50073 & 700 \\
\hline 17 & $\begin{array}{l}\text { Merge point between the rivers Tanda } \\
\text { and Quizende }\end{array}$ & Bengo & River & Quibaxe & 14.60326 & 8.51774 & 742 \\
\hline 18 & River Calua & Bengo & River & Pango Aluquem & 14.4808 & 8.66434 & 580 \\
\hline 19 & River Úcua (1) & Bengo & River & Cacamba & 14.64988 & 8.64988 & 329 \\
\hline 20 & River Úcua (2) & Bengo & River & Ucua & 14.16441 & 8.65763 & 240 \\
\hline 21 & $\begin{array}{l}\text { Lake Panguila (1) (potential type-locality } \\
\text { for Bulinus canescens) }\end{array}$ & Bengo & Lake & Porto mangueiras & 13.45476 & 8.71929 & 0 \\
\hline 22 & Lake Panguila (2) & Bengo & Lake & Porto mangueiras & 13.45443 & 8.72003 & 9 \\
\hline 23 & Canal from Lake Panguila (1) & Bengo & Canal & Burgalheira escola & 13.55499 & 8.79566 & 18 \\
\hline 24 & Canal from Lake Panguila (2) & Bengo & Canal & Burgalheira escola & 13.55088 & 8.80342 & 15 \\
\hline 25 & Canal from Lake Panguila (3) & Bengo & Canal & Burgalheira escola & 13.54862 & 8.80783 & 16 \\
\hline 26 & Bridge over the Lake Panguila & Luanda & Lake & Panguila & 13.43812 & 8.73092 & 18 \\
\hline 27 & River Bengo & Luanda & River & Funda & 13.55313 & 8.84427 & 19 \\
\hline 28 & $\begin{array}{l}\text { Lake Quilunda (1) (potential type-locality } \\
\text { for Bulinus canescens) }\end{array}$ & Luanda & Lake & Muculo & 13.58681 & 8.86712 & 25 \\
\hline 29 & $\begin{array}{l}\text { Lake Quilunda (2) (potential type-locality } \\
\text { for Bulinus canescens) }\end{array}$ & Luanda & Lake & Muculo & 13.58789 & 8.86708 & 23 \\
\hline 30 & Lake Quilunda (3) & Luanda & Lake & Cadianzala & 13.62339 & 8.90514 & 20 \\
\hline 31 & Artificial lagoon on Aurora farm & Luanda & Lagoon & Onga Zanga & 13.67903 & 9.0191 & 31 \\
\hline 32 & Pool formed by River Kwanza & Luanda & Pool & Candimba/Muxima & 13.96911 & 9.53437 & 21 \\
\hline 33 & Cambemba Lagoon (1) & Luanda & Lagoon & Cacefo & 13.77959 & 9.27866 & 18 \\
\hline 34 & Cambemba Lagoon (2) & Luanda & Lagoon & Cacefo & 13.78779 & 9.26822 & 16 \\
\hline 35 & Canal from the River Kwanza & Luanda & Canal & Caquila & 13.468 & 9.1594 & 4 \\
\hline 36 & $\begin{array}{l}\text { Pool near Aldeia Nova (1) (type-locality } \\
\text { for Bulinus crystallinus) }\end{array}$ & Kwanza Norte & Pool & Aldeia Nova & 14.24768 & 9.21573 & 201 \\
\hline 37 & Pool near Aldeia Nova (2) & Kwanza Norte & Pool & Aldeia Nova & 14.36089 & 9.1771 & 239 \\
\hline 38 & Unknown stream near Golungo Alto & Kwanza Norte & River & Golungo Alto & 14.59253 & 9.17718 & 308 \\
\hline 39 & River Luinha & Kwanza Norte & River & Luinha & 14.66055 & 9.21806 & 333 \\
\hline 40 & River Lussué & Kwanza Norte & River & Lussue & 14.83917 & 9.2864 & 591 \\
\hline
\end{tabular}


Table 1 Sites visited during field-work (Continued)

\begin{tabular}{|c|c|c|c|c|c|c|c|}
\hline Code & Name & Province & Type & Closest village & Latitude (E) & Longitude (S) & Altitude \\
\hline 41 & River Muembege (1) & Kwanza Norte & River & N'Dalatando & 14.92749 & 9.28563 & 793 \\
\hline 42 & River Muembege (2) & Kwanza Norte & River & N'Dalatando & 14.92782 & 9.28517 & 804 \\
\hline 43 & River Muembege (3) & Kwanza Norte & River & N'Dalatando & 14.92582 & 9.28576 & 801 \\
\hline 44 & $\begin{array}{l}\text { River Cangulungo (potential } \\
\text { type-locality for Bulinus crystallinus) }\end{array}$ & Kwanza Norte & Stream & N'Dalatando & 14.89462 & 9.31063 & 759 \\
\hline 45 & River Muembege (4) & Kwanza Norte & River & N'Dalatando & 14.89815 & 9.33458 & 725 \\
\hline 46 & River Muembege (5) & Kwanza Norte & River & N'Dalatando & 14.91162 & 9.31264 & 765 \\
\hline 47 & River Cambota & Kwanza Norte & River & Cacuso & 15.75334 & 9.4143 & 1045 \\
\hline 48 & River Quimona & Malanje & River & Soqueco & 15.92973 & 9.1746 & 971 \\
\hline 49 & River Memba & Malanje & River & Bingwe & 16.07151 & 9.23689 & 1079 \\
\hline 50 & Unknown stream near Carlanga & Malanje & Stream & Carlanga & 15.97861 & 9.16565 & 1026 \\
\hline 51 & River Quialeva & Malanje & River & Calandula & 15.98556 & 9.0786 & 1084 \\
\hline 52 & River Lucala & Malanje & River & Vulabongo & 15.97136 & 9.12839 & 959 \\
\hline 53 & River Sende (1) & Malanje & River & Capoza & 15.96031 & 9.15152 & 986 \\
\hline 54 & River Sende (2) & Malanje & River & Capoza & 15.95987 & 9.1505 & 983 \\
\hline 55 & River Camahonjo (1) & Malanje & River & Mangumbala & 16.13156 & 9.25788 & 1092 \\
\hline 56 & $\begin{array}{l}\text { Source of the River Cota (type-locality } \\
\text { for Bulinus angolenses) }\end{array}$ & Malanje & River & Mangumbala & 16.13693 & 9.26186 & 1083 \\
\hline 57 & River Camahonjo (2) Source & Malanje & River & Leco Segundo & 16.13938 & 9.25468 & 1111 \\
\hline 58 & River Calulo & Malanje & River & Quissol & 16.46778 & 9.58705 & 1038 \\
\hline 59 & $\begin{array}{l}\text { River Quastimbala (1) (type-locality for } \\
\text { Biomphalaria salinarum) }\end{array}$ & Malanje & River & Catunga & 16.48999 & 9.59848 & 1047 \\
\hline 60 & $\begin{array}{l}\text { River Quastimbala (2) (type-locality for } \\
\text { Biomphalaria salinarum) }\end{array}$ & Malanje & River & Catunga & 16.49321 & 9.59602 & 1051 \\
\hline
\end{tabular}

${ }^{a}$ Metres above sea level

The PCR conditions were as outlined by [13] except an annealing temperature of $60{ }^{\circ} \mathrm{C}$ instead of $40{ }^{\circ} \mathrm{C}$ was used. Sequencing was performed on an Applied Biosystems 3730XL analyser (Life Technologies, UK).

\section{Extraction and amplification of cox1 and ITS2 fragments of Schistosoma haematobium}

Punches $(2.0 \mathrm{~mm})$ were taken from the centre of each cercarial spot on FTA cards and $\mathrm{pH}$ elution performed to remove the DNA from the card matrix [14]. A 1500 bp fragment was amplified from $3 \mu$ of genomic DNA using the Cox1_Schist_5' and Cox1_Schist_3' [15] primers and illustra $^{\mathrm{Tm}}$ puReTaq Ready-To-Go PCR Beads (GE Healthcare Life Sciences, UK). The following cycling conditions were used: $95{ }^{\circ} \mathrm{C}$ for $1 \mathrm{~min}, 40$ cycles of $95{ }^{\circ} \mathrm{C}$ for $30 \mathrm{~s}, 40{ }^{\circ} \mathrm{C}$ for $30 \mathrm{~s}$ and $72{ }^{\circ} \mathrm{C}$ for $2 \mathrm{~min}$, with a 7 min extension of $72{ }^{\circ} \mathrm{C}$. In addition, ITS2 was amplified as it would identify schistosome hybrids, the PCR used ITTS1 and ITTS2 primers [15] with the above conditions except the annealing temperature of $56{ }^{\circ} \mathrm{C}$ instead of $40{ }^{\circ} \mathrm{C}$. PCR products were cleaned using the QIAquick PCR purification kit (Qiagen, UK). Samples were sequenced in both orientations on an Applied
Biosystems 3730XL analyser running BigDye v3.1 sequencing chemistry.

\section{Phylogenetic analysis of sequence data}

The electropherograms produced were checked and cox1 sequences edited using Geneious, version 6.1.8 (http://www.geneious.com [16]). Sequences were compared to database entries by performing BLAST searches via the National Center for Biotechnology Information against GenBank and EMBL sequence databases; and aligned with reference material [13] using Geneious version 5.6. The cox 1 data for all taxa were analysed solely as nucleotides and phylograms were produced from the alignments using PhyML with automatic model selection by SMS $[17,18]$ using the Akaike Information Criterion. Branch support was estimated using 1000 bootstrap replications. Additionally, B. truncatus (Niger [13]) was used as an outgroup for the Bulinus forskalii species group, and B. forskalii (Niger [13]) was used for the Bulinus africanus species group. Different outgroups were used for the different analyses based on suitability (geographical and sister taxa). DNA sequences have been submitted to the European Nucleotide Archive with accession numbers LT671915-LT671982. 


\section{Results}

\section{Locations}

A total of 60 sites were visited and included rivers, streams and canals. Sites on the Bengo, Kwanza and Cuije River Basins displayed the highest mean snail biodiversity, with more than 3 genera identified (Table 2). In total, $73 \%$ of sites had a mud substrate (usually associated with roots of aquatic and peripheral vegetation), with little domestic animal water contact observed (of the 60 sites 3\% had cows, $8 \%$ goats, $13 \%$ pigs, $7 \%$ dogs, $3 \%$ horses and $7 \%$ had chickens). Wildlife was present in some sites: in $18 \%$ of the sites aquatic reptiles were observed or believed to be present, in $3 \%$ of the sites hippopotamus were observed or believed to be present, and in $27 \%$ of the sites aquatic birds were observed. Finally, the most prevalent vegetation identified in all 60 sites was grass (57\%), macrophyte plants (52\%), lilies (37\%), rushes (35\%) and water hyacinths (13\%), in descending order. The water chemistry and other factors did not significantly impact on the presence or absence of snail species (Table 2; Additional file 1: Table S1).

\section{Malacology}

In total 1265 snail samples were accessioned in to SCAN. According to morphological evaluations, species of a total nine snail genera were identified: Biomphalaria, Bulinus, Gyraulus, Lanistes, Lentorbis, Lymnaea, Melanoides, Physa and Succinea..Of most significance for schistosomiasis transmission, was finding of Bulinus globosus (105 specimens), Bulinus canescens (3 specimens), Bulinus angolensis (8 specimens), Bulinus crystallinus (> 200 specimens) and Biomphalaria salinarum (23 specimens) in what are believed to be their type-localities and other habitats (Fig. 1).

Subsets of the snails (representatives of every site and species) were used for molecular analyses $(n=133)$. Bulinus globosus and B. forskalii were the most abundant snail species and covered the greatest range of sites; 403 specimens in 21 sites and 390 specimens in 12 sites, respectively. Other species were: Lymnaea natalensis, Melanoides tuberculata, Lanistes ovum, Gyraulus costulatus, Lentorbis benguelensis, Succinea sp. and Physa acuta.

\section{Analysis of sequence data}

The mitochondrial cox 1 gene sequence generated for all the Bulinus species in this study was found to be variable, in agreement with previous work [13]. Initially the universal "Folmer" primers, effective across a wide range of taxa, were used that cover approximately the first 600 bp of cox 1 ; however for B. globosus and B. angolensis these standard primers did not amplify the target region. By examining whole mitochondrial DNA sequence (unpublished) new primers were designed for these species, which allowed the amplification of a comparable region of DNA sequence. Phylogenetic analysis of the sequence data for snails identified as B. globosus and B. angolensis revealed that the $B$. globosus snails collected for this study formed a monophyletic group distinct from $B$. globosus found elsewhere (Fig. 2). Additionally, the snails identified as $B$. angolensis formed another distinct clade with the specimen from Wright's 1957 study, previously identified as B. globosus. Snails from Angola identified as $B$. forskalii were not monophyletic with respect to $B$. canescens or B. crystallinus, whereas B. forskalii (and B. camerunensis) from elsewhere formed a separate clade (Fig. 3). Phylogenetic analysis of Biomphalaria salinarum suggested a close affinity with Biomphalaria pfeifferi (not shown); DNA sequence was highly similar to B. pfeifferi for the cox 1 barcoding region (up to $99 \%$ similarity).

\section{Parasitology}

Of the Bulinus spp. and Biomphalaria spp. specimens collected, only Bulinus globosus (25 in total) was found to be shedding Schistosoma cercariae. These were found in 2 sites: Site 5 [ 20 out of 105 snails shedding (19\% prevalence)] and site 60 , the source of the River Cata [5 out of $68(0.07 \%$ prevalence)]. The cox 1 and ITS2 sequences of the cercariae sampled corresponded to haplotype $\mathrm{H} 1$ of $S$. haematobium, by far the most widespread across Africa [19]. Apart from human parasites, B. globosus specimens were also found to be shedding Trichobilharzia, echinostome, amphistome and strigeid cercariae. Bulinus crystallinus specimens were found to be shedding cercariae of Trichobilharzia

Table 2 Summary of water chemistry parameters and biodiversity of each river basin

\begin{tabular}{|c|c|c|c|c|c|}
\hline River basin & Dande/Úcua & Bengo & Kwanza & Lucala & Cuije \\
\hline Number of sites & 20 & 11 & 4 & 22 & 3 \\
\hline Altitude (m) & $232(12-762)$ & $17(0-31)$ & $14(4-21)$ & $220(201-1111)$ & 1045 (1038-1051) \\
\hline Temperature $\left({ }^{\circ} \mathrm{C}\right)$ & $28.3(25.4-32.8)$ & $30.4(27.8-33.1)$ & 32.7 (30.9-33.6) & $31.5(22.5-32.1)$ & $24.2(22.1-27.2)$ \\
\hline TDS (ppm) & $205(42-736)$ & $398(138-830)$ & $69(59-80)$ & $119(26-612)$ & $204(156-276)$ \\
\hline $\mathrm{pH}$ & $7.75(6.96-8.79)$ & $7.71(6.88-8.70)$ & $7.02(6.54-7.82)$ & $9.26(6.85-9.60)$ & $7.76(7.07-8.31)$ \\
\hline Conductivity (m/s) & $245(59-795)$ & $562(194-1171)$ & $96(83-112)$ & $159(65-860)$ & $288(220-397)$ \\
\hline Salinity (ppm) & $125(33-389)$ & $276(95-581)$ & $52(46-58)$ & $84(35-415)$ & 139 (106-190) \\
\hline Average biodiversity (no. of genera) & $1.35(0-4)$ & $3.27(2-5)$ & $3.25(3-4)$ & $1.5(0-2)$ & $3.3(1-5)$ \\
\hline
\end{tabular}

Note: Data are given as mean (range) 


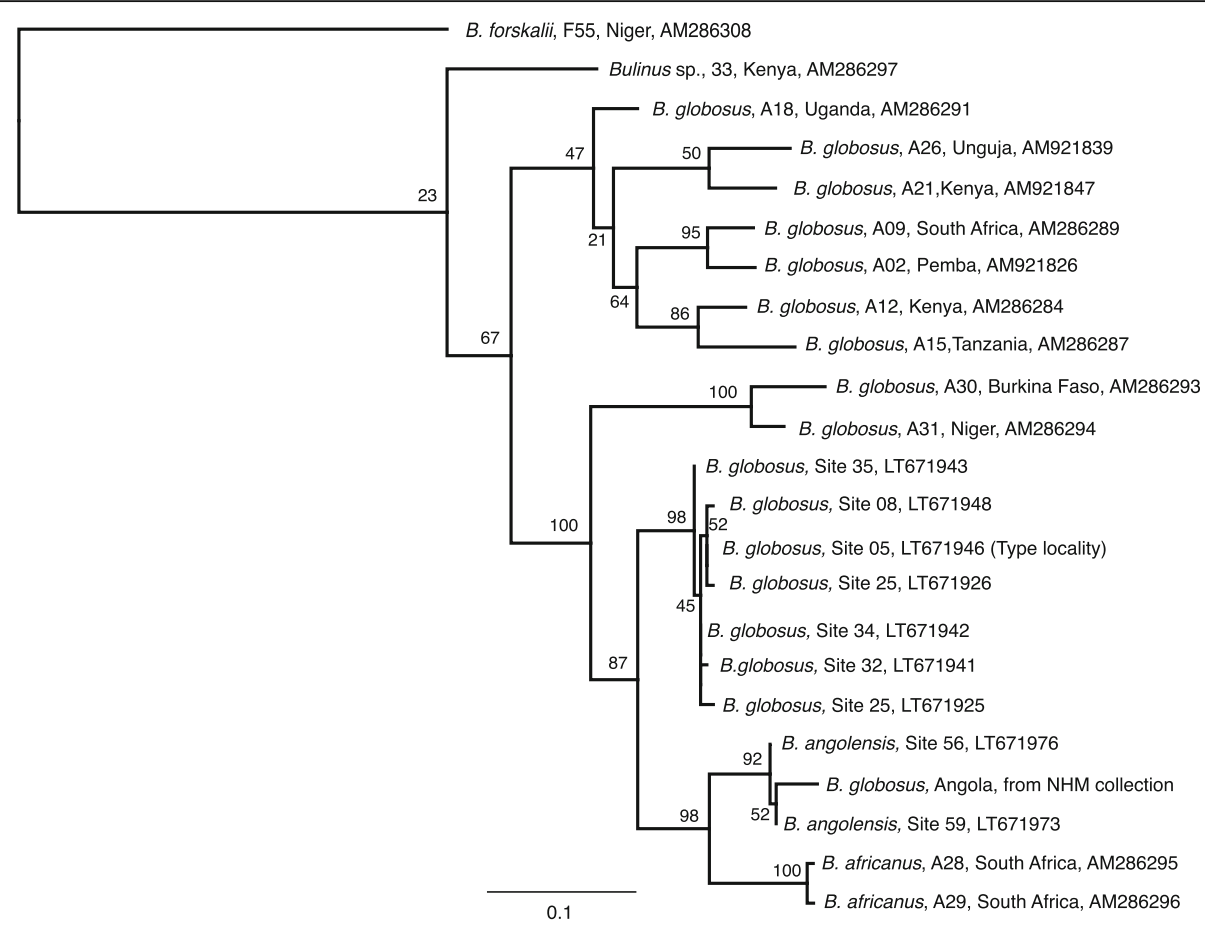

Fig. 2 Maximum Likelihood tree for Bulinus globosus and B. angolensis based on cox1 sequences. Maximum likelihood tree of a 613 bp fragment of the cytochrome c oxidase subunit 1 (cox1) gene for B. globosus and B. angolensis collected in this study, with additional previously published sequences [13]. B. forskalii was selected as the outgroup. Numbers at the nodes indicate bootstrap support (1000 pseudoreplications). The scalebar indicates substitutions per nucleotide site

and echinostomes. The non-schistosome cercariae were identified using morphology and swimming characteristics.

\section{Discussion}

Angola is a particularly rich area for type-localities of both Bulinus and Biomphalaria species and it is of interest that similar diversity of snails still exists in locations sampled 56 years previously. The fact that the survey was conducted in November/December had its advantages and disadvantages. Importantly, C. A. Wright visited these same areas in November/December of 1957 [6], giving concordance in sampling season between the two studies. However, the survey was conducted at the start of the rainy season, when many of the rivers and tributaries were running low or even dry (namely in the Úcua River basin). Nevertheless, the level of snail biodiversity in some sites was high, as well as the abundance. For example, in the Caxito canal (sites 3 and 4), the number of Melanoides tuberculata and Physa acuta was large and may in part account for the absence of Bulinus spp.

The 37 recognised species of Bulinus have been divided for convenience into fourgroups: the $B$. africanus group, the $B$. reticulatus group, the $B$. forskalli group and the B. truncatus/tropicus complex [9], while others studies have argued for subdivision of the genus into three genera [20]. The lack of clear morphological characters for species identification provided the impetus to search for molecular solutions and cox1 barcoding was shown to provide good species discrimination and agreed for the most part with the taxonomy based on morphological criteria [9]. The dataset generated here can be added to and compared with the earlier cox 1 sequences considered by Kane et al. [13].

One of the most striking findings is the close association observed between B. globosus and B. angolensis. The latter species had previously been placed in a different species groups: $B$. globosus within the $B$. africanus group while $B$. angolensis had been included in the $B$. tropicus/truncatus complex. Brown [9] made the point that treatment of this species is unclear partly because the chromosome number and molecular properties were unknown. Wright [6] noted that he did not have sufficient material to assess properly the relationships of this species or to fully describe the range of variation. Our own material has so far been limited but based on current data it is safe to consider $B$. angolensis as a member of the $B$. africanus group and not a member of the $B$. tropicus/truncatus complex.

Another observation that deserves further, detailed studies is the relationship of the samples included as $B$. 


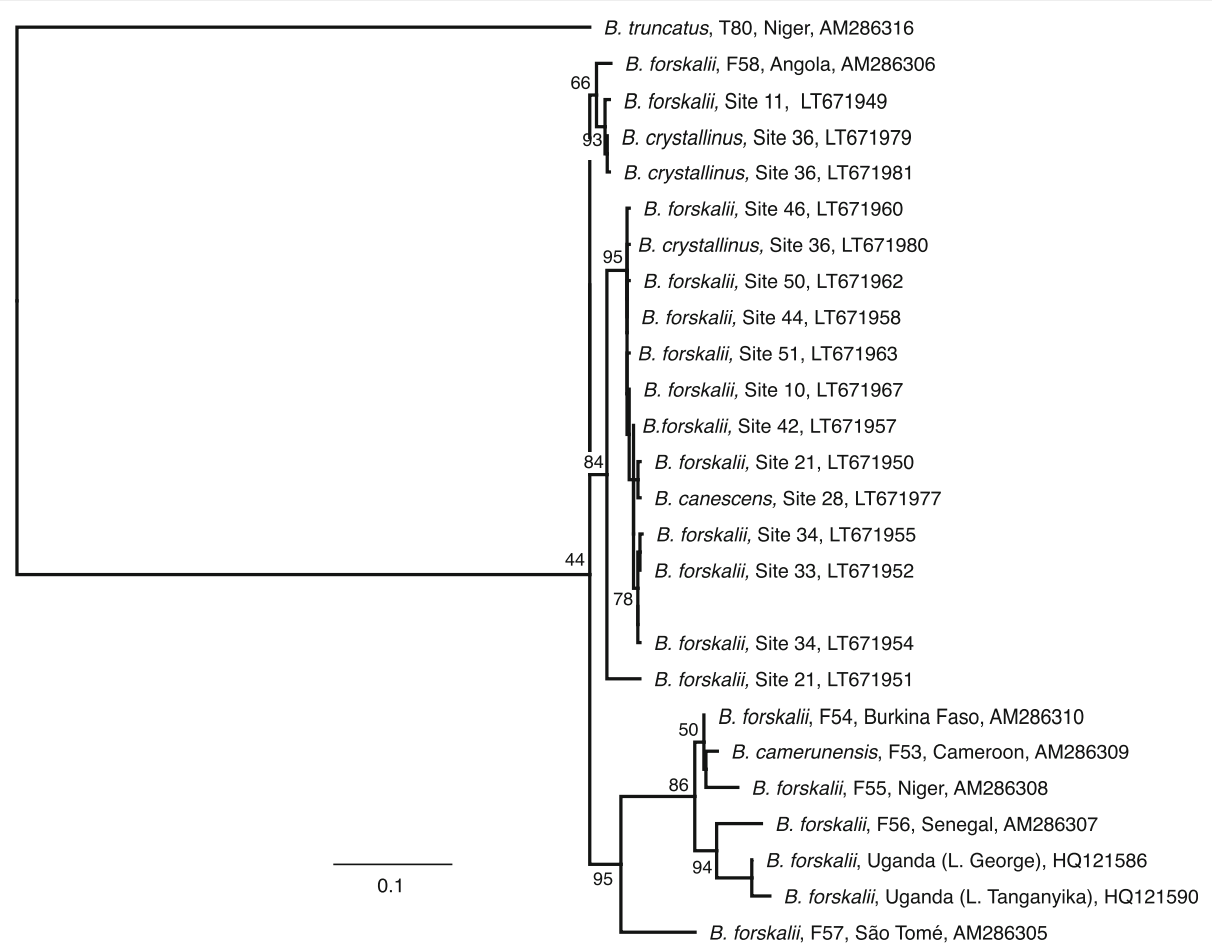

Fig. 3 Maximum Likelihood tree for Bulinus forskalii, B. crystallinus and B. canescens based on cox1 sequences. Maximum likelihood tree of a 590 bp fragment of the cytochrome c oxidase subunit 1 (cox1) gene for Bulinus forskalii, B. crystallinus and B. canescens collected in this study, with additional previously published sequences. B. truncatus was selected as the outgroup. Numbers at the nodes indicate bootstrap support (1000 replications). The scale-bar indicates substitutions per nucleotide site

globosus. Kane et al. [13] drew attention to the fact that there was a clear division between samples originating from East and West Africa. Bulinus globosus has almost a pan-African distribution. The trees generated here on cox 1 sequence data suggest that B. globosus from Angola are quite distinct from other geographical areas. This observation might cause a taxonomic dilemma as the samples analysed here are in fact from the type-locality and hence represent the "true" B. globosus. It is clear that this snail species, which acts as an important host for S. haematobium and other schistosome species throughout its range, needs a more thorough investigation. While changes in nomenclature might eventually be warranted we suggest that further sampling is required and more comprehensive molecular data are needed before such changes are made.

Additionally, a single sample from C. A. Wright's 1957 collection held at the Natural History Museum as part of SCAN was included in these analyses and can be seen to be most similar to B. angolensis from the 2013 collection. The cox 1 sequence gained from this snail is particularly interesting as the specimen had been held in industrial methylated spirit for the past 60 years; samples held in this way are generally fragmented as the DNA can be damaged by this storage medium. Wright's original identification on morphological grounds alone was that this specimen was best considered as B. globosus but the molecular data strongly supports the grouping with $B$. angolensis.

Other specimens collected at type-localities were from the $B$. forskalii species group. Again, analysis of the cox 1 regions shows that the samples from Angola are diverse and not necessarily falling into the groups that were previously expected. It is clear that there are at least two different groupings (Fig. 3); first "B. forskalii" types with the inclusion of $B$. canescens potentially as a subgroup of $B$. forskalii, and the B. crystallinus types which are distinct from the main clade. It is of interest to note here that Brown [9] discussed the lumping of these species and thought that there may be up to 12 separate species within Angola; these points were also made by Jones et al. [20] and Kane et al. [13]. Species assignment based on locality and morphology looks somewhat arbitrary when compared with phylogenetic analysis using sequence data, especially for the B. forskalii group. While cox 1 barcoding has been used extensively for snail vectors (e.g. [13]), it is clear that further investigation at the molecular level is needed to elucidate and identify and relationship of species within this species group prior to any changes in nomenclature.

Biomphalaria species were collected from only a couple of locations in this study, ultimately only two 
specimens had unique $\operatorname{cox} 1$ sequence and therefore were included in this analysis. From the analysis $B$. salinarum is found at two sites and is most closely related to $B$. pfeifferi.

With reference to the schistosome species found in this study, to our knowledge this is the first time that $S$. haematobium has been genetically typed from Angola. Schistosoma haematobium cercariae recovered from $B$. globosus showed to be standard H1 cox1 haplotype and the three samples examined had a low diversity (only 3 single nucleotide changes). This is what we would expect from the African mainland from previous studies [19]. No other animal schistosomes were encountered, but a range of species of cercariae were produced by a number of species of snail; this is usual in water-contact sites in use by humans, animals (wild and domestic) and birds. Interestingly, Biomphalaria species were not common suggesting that intestinal schistosomiasis caused by $S$. mansoni is unlikely to be a major public health problem in the region [21].

As schistosomiasis control programmes gather pace it is important that malacological studies are carried out to help guide mapping of disease transmission and the planning of control interventions. Focus is moving towards the elimination of schistosomiasis $[4,5]$ and a recent analysis has shown the value of interventions that control snail populations [22]. The increase in data collection from sites, with geo-referencing, and with molecular techniques gives a more detailed view on transmission and where to target control efforts. This study has initiated mapping of snail distributions in four provinces of Angola, important site localities have been geo-referenced and photographic records have been made at each of the collection points. There is now a need to extend the survey into other regions of Angola.

\section{Conclusions}

The findings reported here provide new insights into the molecular diversity within and between the Bulinus species examined. The samples of medically important snails collected and identified by the barcoding approach will be subjected to further more in depth molecular sequencing to help elucidate the relationships with Bulinus and Biomphalaria species from other African regions.

\section{Additional file}

Additional file 1: Table S1. Details of snails at each site. (XLS $48 \mathrm{~kb}$ )

\section{Acknowledgements}

Thanks are given to Artur Luciano, Alice M. Sicato and Pedro Van-Dúnem from the Programa Nacional de Doenças Tropicais Negligenciadas (PNDTNs), Ministério da Saúde de Angola (MINSA), Angola, for their work during the field collections. The project provided an opportunity for discussions between NHM/CISA NNTDCP/FCG concerning research and control of Neglected Tropical Diseases
(NTDs) in Angola and provided training for CISA/NNTDCP personnel in snail identification and schistosomiasis transmission studies.

\section{Funding}

This study received financial support from the promoters of CISA (Camões - Instituto da Cooperação e da Língua, I.P, Fundação Calouste Gulbenkian, Governo Provincial do Bengo and Ministério da Saúde de Angola), which played no role in either the design of the study or in interpreting the findings. FA is financially supported by the Wellcome Trust (SCAN Project WT104958MA).

\section{Availability of data and materials}

The datasets generated during and/or analysed during the current study that are not included in this published article are available from the

Schistosomiasis Collection at the Natural History Museum (SCAN) http:// scan.myspecies.info. DNA sequences have been submitted to the European Nucleotide Archive with accession numbers LT671915-LT671982.

\section{Authors' contributions}

Conception and design of the study: JCSF, DR, FA and MB. Acquisition of data: FA, JCSF, DR, AE, RP, CM, AS and MB. Analysis and interpretation of data: FA, JCSF and AE. Drafting the article: FA, JCSF, AE and DR. Revising the article critically for important intellectual content: FA, AE, JCSF, MB and DR. All authors read and approved the final manuscript.

Ethics approval and consent to participate

Not applicable.

\section{Consent for publication}

Not applicable.

\section{Competing interests}

The authors declare that they have no competing interests.

\section{Publisher's Note}

Springer Nature remains neutral with regard to jurisdictional claims in published maps and institutional affiliations.

\section{Author details}

${ }^{1}$ Department of Life Sciences, Natural History Museum, Wolfson Wellcome Biomedical Laboratories, Cromwell Road, London SW7 5BD, UK. ${ }^{2}$ London Centre for Neglected Tropical Disease Research, London, UK. ${ }^{3}$ Centro de Investigação em Saúde de Angola (Health Research Center in Angola), Rua direita do Caxito, Hospital Provincial, Bengo, Angola. ${ }^{4}$ Department of Parasitology, Liverpool School of Tropical Medicine, Pembroke Place, L3 5QA, Liverpool, UK. ${ }^{5}$ Escola Superior de Tecnologia da Saúde de Lisboa, Lisbon, Portugal.

Received: 21 March 2017 Accepted: 19 September 2017 Published online: 10 October 2017

\section{References}

1. WHO. Country Profile: Preventive chemotherapy and transmission control. Geneva: World Health Organization; 2010. http://www.who.int/neglected_ diseases/preventive_chemotherapy/databank/CP_Angola.pdf?ua=1

2. INE. 2014 National Census, vol. 2014: Instituto Nacional de Estatística. http:// www.ine.gov.ao

3. WHO. Preventive Chemotherapy in Human Helminthiasis. Coordinated use of Anthelminthic Drugs in Human Interventions: a Manual for Health Professionals and Programme Managers. Geneva: World Health Organization; 2006.

4. Rollinson D, Knopp S, Levitz S, Stothard JR, Tchuem Tchuenté L-A, Garba A, et al. Time to set the agenda for schistosomiasis elimination. Acta Trop. 2013;128:423-40.

5. WHO. Accelerating work to overcome the global impact of neglected tropical diseases: a roadmap for implementation. Geneva: World Health Organization; 2011.

6. Wright CA. The freshwater gastropod mollusca of Angola. Bull Brit Mus (Nat Hist). 1963;10(8):447-528. 
7. Morelet A. Coquilles nouvelles recueilles par le Dr. Fr. Welwitsch dans l'Afrique équatoriale, et particulierèment dans les provinces portugaises d'Angola et de Benguela. Conchyliol. 1866;6(3):153-63.

8. Morelet A. Mollusques terrestres et fluviatiles. Voyage du Dr. Friederich Welwitch. Ballière, Paris: Bailliere; 1868.

9. Brown D. Freshwater snails of Africa and their medical importance. Oxford: Taylor \& Francis; 1994.

10. Gower CM, Gabrielli AF, Sacko M, Dembelé R, Golan R, Emery AM, et al. Population genetics of Schistosoma haematobium: development of novel microsatellite markers and their application to schistosomiasis control in Mali. Parasitology. 2011;138:978-94.

11. Emery AM, Allan FE, Rabone ME, Rollinson D. Schistosomiasis collection at NHM (SCAN). Parasit Vectors. 2012;5:185.

12. Folmer O, Black M, Hoeh W, Lutz R. DNA primers for amplification of mitochondrial cytochrome c oxidase subunit I from diverse metazoan invertebrates. Mol Mar Biol Biotechnol. 1994;5:294-9.

13. Kane RA, Stothard JR, Emery AM, Rollinson D. Molecular characterization of freshwater snails in the genus Bulinus: a role for barcodes? Parasit Vectors. 2008;1:15.

14. Webster BL, Rabone M, Pennance T, Emery AM, Allan F, Gouvras AN, et al. Development of novel multiplex microsatellite polymerase chain reactions to enable high-throughput population genetic studies of Schistosoma haematobium. Parasit Vectors. 2015;8:432.

15. Lockyer AE, Olson PD, Østergaard P, Rollinson D, Johnston DA, Attwood SW et al. The phylogeny of the Schistosomatidae based on three genes with emphasis on the interrelationships of Schistosoma Weinland, 1858 Parasitology. 2003;126(03):203-24.

16. Kearse M, Moir R, Wilson A, Stones-Havas S, Cheung M, Sturrock S, et al. Geneious Basic: an integrated and extendable desktop software platform for the organization and analysis of sequence data. Bioinformatics. 2012;28(12): 1647-9.

17. Guindon S, Gascuel O. A Simple, fast, and accurate algorithm to estimate large phylogenies by maximum likelihood. Syst Biol. 2003;52:696-704.

18. Lefort V, Longueville J-E, Gascuel O. ATGC: PhyML with automatic model selection by SMS. http://www.atgc-montpellier.fr/phyml-sms. Accessed 12 Oct 2016.

19. Webster BL, Emery AM, Webster JP, Gouvras A, Garba A, Diaw O, et al. Genetic diversity within Schistosoma haematobium: DNA barcoding reveals two distinct groups. PLoS Negl Trop Dis. 2012;7(2):10.

20. Jones CS, Rollinson D, Mimpfoundi J, Ouma J, Kariuki HC, Noble LR. Molecular evolution of freshwater snail intermediate hosts within the Bulinus forskalii group. Parasitology. 2001;123:S277-92.

21. Sousa-Figueiredo JC, Gamboa D, Pedro JM, Fançony C, Langa AJ, Soares Magalhães RJ, et al. (2012) Epidemiology of malaria, schistosomiasis, geohelminths, anemia and malnutrition in the context of a demographic surveillance system in Northern Angola. PLoS One. 2012;7(4):e33189.

22. Sokolow SH, Wood CL, Jones IJ, Swartz SJ, Lopez M, Hsiesh MH, et al. Global assessment of schistosomiasis control over the past century shows targeting the snail intermediate host works best. PLoS Negl Trop Dis. 2016; https://doi.org/10.1371/journal.pntd.0004794.

\section{Submit your next manuscript to BioMed Central and we will help you at every step:}

- We accept pre-submission inquiries

- Our selector tool helps you to find the most relevant journal

- We provide round the clock customer support

- Convenient online submission

- Thorough peer review

- Inclusion in PubMed and all major indexing services

- Maximum visibility for your research

Submit your manuscript at www.biomedcentral.com/submit 